\title{
PENGEMBANGAN PRODUK FUNDING KSPPS BMT AMANAH UMMAH JAWA TIMUR']
}

\author{
Indi Masita Lisdawami \\ Mahasiswa Program Studi Ekonomi Islam-Fakultas Ekonomi dan Bisnis-Universitas Airlangga \\ Email: indi.masita-12@feb.unair.ac.id \\ Imron Mawardi \\ Departemen Ekonomi Syariah-Fakultas Ekonomi dan Bisnis-Universitas Airlangga \\ Email: Imron.Mawardi@feb.unair.ac.id
}

\begin{abstract}
:
BMT must be able to compete with financial institutions, so that BMT must have an appropriate strategy in its operational, including product development strategy. This research aims to find out how funding product development strategy works on KSPPS BMT Amanah Ummah West Java. This research uses qualitative approach with a case study. And it also uses sharia finance product development strategy that is according to Suwailem. Suwailem has three main strategies, which are Imitation, Mutation, and Satisfaction. The data collection technique uses interview to informants in KSPPS BMT Amanah Ummah.

The result shows, KSPPS BMT Amanah Ummah has 11 types of deposit products. The first strategy is Imitation Strategy that has transferred conventional product to sharia product. After that, the products development more use mutation strategy. Mutation strategy is a strategy that develops new product by knowing existing product at sharia financial instituion, then it is modified to social needs.
\end{abstract}

Keywords: Baitul Maal Wat Tamwil, Product Development Funding, Imitation Strategy, Mutation Strategy.

\section{Pendahuluan}

Baitul Maal Wattamwil (BMT) merupakan suatu lembaga yang terdiri dari dua istilah, yaitu baitul maal dan baitul tamwil. Baitul maal lebih mengarah pada usaha-usaha pengumpulan dan penyaluran dana yang nonprofit, seperti; zakat, infaq, dan sedekah, adapun baitul tamwil sebagai usaha pengumpulan dan penyaluran dana komersial (Huda, 2010:363). Lembaga ini didirikan dengan maksud untuk memfasilitasi masyarakat bawah yang tidak terjangkau oleh pelayan Bank Syariah atau BPR syariah.

Fenomena yang terjadi dewasa ini adalah banyaknya masyarakat yang datang pada rentenir. Walaupun keberadaan BMT cukup dikenal, Maraknya renternir ditengah-tengah masyarakat mengakibatkan masyarakat semakin terjerumus pada masalah ekonomi yang tidak menentu. Hal ini disebabkan masyarakat membutuhkan pemenuhan dana yang memadai dan pelayanan yang cepat, walaupun ia membayar bunga yang cukup tinggi, besarnya pengaruh rentenir terhadap perekonomian masyarakat tidak lain karena BMT belum mampu memberikan pelayanan yang memadai dalam jumlah dana dan waktu (Sudarsono, 2007:108).

Oleh karena itu, BMT diharapkan mampu berperan lebih aktif dalam memperbaiki kondisi ini. Dalam Al-qur'an Surat Al-Baqarah ayat 275 Allah Berfirman :

1] Jurnal ini merupakan bagian skripsi dari Indi Masita Lisdawami, NIM: 041211433048 , yang diuji pada Januari 2017 


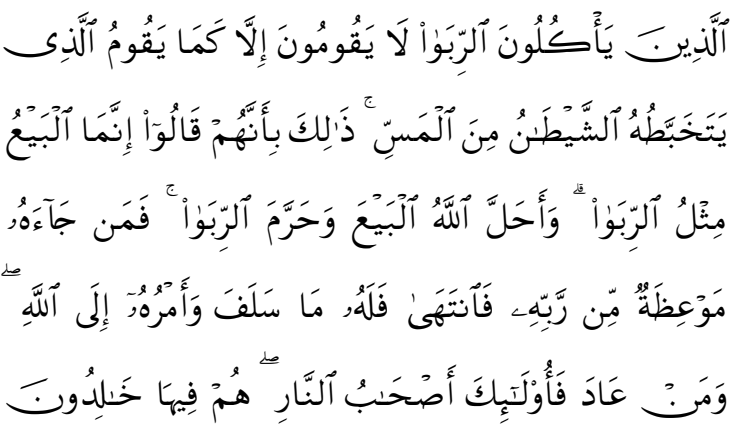

Al-Ladhina Ya'kulūna Ar-Ribā Lā Yaqūmūna 'Illā Kamā Yaqūmu Al-Ladhī Yatakhabbațuhu Ash-Shayțānu Mina AlMassi Dhālika Bi'annahum Qālū 'Innamā Al-Bay'u Mithlu Ar-Ribā Wa 'Aĥalla Allāhu Al-Bay'a Wa Harrama Ar-Ribā Faman Jā'ahu Maw ižatun Min Rabbihi Fāntahá Falahu Mā Salafa Wa 'Amruhu 'llá Allāhi Wa Man 'Āda Fa'ūlā'ika 'Aşhābu An-Nāri Hum Fihā Khālidūna

"Orang-orang yang Makan (mengambil) riba tidak dapat berdiri melainkan seperti berdirinya orang yang kemasukan syaitan lantaran (tekanan) penyakit gila. Keadaan mereka yang demikian itu, adalah disebabkan mereka berkata (berpendapat), Sesungguhnya jual beli itu sama dengan riba, Padahal Allah telah menghalalkan jual beli dan mengharamkan riba. orang-orang yang telah sampai kepadanya larangan dari Tuhannya, lalu terus berhenti (dari mengambil riba), Maka baginya apa yang telah diambilnya dahulu (sebelum datang larangan); dan urusannya (terserah) kepada Allah. orang yang kembali (mengambil riba), Maka orang itu adalah penghuni-penghuni neraka; mereka kekal di dalamnya."

BMT merupakan jawaban dari permasalahan yang ada tidak hanya mengatasi masalah pembiayaan, BMT diharapkan mampu mengedukasi masyarakat untuk gemar menabung. Menabung mendidik masyarakat untuk memikirkan jangka panjang kehidupan yang ingin dicapai dengan memanage setiap dana yang dimilkinya. Sesuai dengan Firman Allah dalam QS. Al-Furqan ayat 67 :

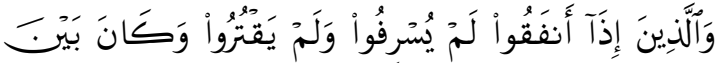

$$
\begin{aligned}
& \text { ذَالِكَ قَتَامَا }
\end{aligned}
$$

"Wa Al-Ladhīna 'Idhā 'Anfaqū Lam Yusrifū Wa Lam Yaqturū Wa Kāna Bayna Dhālika Qawāmāan

"Dan orang-orang yang apabila membelanjakan (harta), mereka tidak berlebihan, dan tidak (pula) kikir, dan adalah (pembelanjaan itu) di tengahtengah antara demikian."

Berbagai macam produk yang ditawarkan oleh BMT akan langsung menyentuh pada aktifitas yang diperlukan oleh masyarakat, disamping itu sebagai lembaga intermediasi BMT haruslah mampu bersaing dengan lembaga keuangan sejenis maupun lembaga keuangan konvesional. Banyaknya produk sejenis yang dimiliki lembaga keuangan lain seperti Simpanan Mudharabah masih belum sepenuhnya mampu membuat masyarakat gemar menabung, karena banyaknya kendala seperti minimnya cabang, tidak adanya ATM dan lain sebagainya membuat orang enggan menabung pada BMT, sehingga BMT harus memiliki strategi yang tepat di dalam operasionalnya untuk tetap eksis di kalangan masyarakat, salah satunya di dalam strategi pengembangan produk.

Meskipun BMT terdepan dalam urusan pengentasan kemiskinan dan memiliki beberapa keunggulan lain pada produknya, proses pengembangan produk tetap harus dilakukan untuk 
meningkatkan keunggulan bersaing pada BMT itu sendiri. Menurut Mawardi (2015) hasil riset bank Indonesia dengan LPEl pada tahun 2013 menunjukkan ada tiga kendala utama yang penting untuk pengembangan BMT yaitu $61 \%$ manajer BMT seluruh Jatim mengatakan penambahan jaringan BMT sangat diperlukan, nomer dua pengembangan produk baru dan terakhir kurangnya kucuran modal. Dilihat dari hasil penelitian tersebut, pengembangan produk baru sangat penting menurut seluruh manajer BMT Jatim yang diwawancarai.

\section{Menurut Sudarsono (2007:109) dalam bukunya Bank dan Lembaga} Keuangan Syariah: Deskripsi dan llustrasi:

BMT memerlukan inovasi
dikarenakan produk yang
ditawarkan kepada masyarakat
relatif tetap, dan kadangkala BMT
tidak mampu menangkap gejala-
gejala ekonomi dan bisnis yang
ada di masyarakat. hal ini timbul
dari berbagai sebab; pertama,
timbulnya kekhawatiran tidak
sesuai dengan syariah; kedua;
memahami produk BMT hanya
seperti yang ada. Kebebasan
dalam melakukan inovasi produk
yang sesuai dengan syariah
diperlukan supaya BMT mampu
tetap eksis ditengah-tengah
masyarakat.

Menurut Bapak Sofyan selaku Sekretaris Pengurus pada KSPPS BMT Amanah Ummah :

"Permasalahan BMT terhadap penyaluran pembiayaan yang ada bersumber utama pada permasalahan pendanaan yang ada pada BMT. kondisi real BMT tidak bisa disamakan dengan teori yang ada. Funding pada BMT sangat membutuhkan strategi pengembangan produk yang efektif dan efisien sehingga BMT mampu berkembang dan bersaing dengan lembaga keuangan mikro syariah lainnya dalam melayani umat. BMT juga belum mampu menyentuh semua lapisan masyarakat karena BMT pun tidak bisa menjadi lilin yang mampu menerangi sekitarnya namun menghancurkan dirinya sendiri, permasalahan yang kompleks mengenai renternir tersebut pernah pula ditangani oleh BMT Amanah Ummah namun, karena akan berulang seperti itu dan dana yang ada terkadang tidak mencukupi untuk mengakomodir seluruh pembiayaan yang diajukan oleh masyarakat. oleh karena itu permasalahan utama BMT yang ada terletak pada perlunya pengembangan produk pendanaan/ funding kepada BMT. KSPPS BMT Amanah Ummah sebagai salah satu lembaga keuangan syariah yang memberikan solusi dengan menawarkan berbagai macam produk, untuk memasarkan produk dan jasa KSPPS BMT Amanah Ummah mempunyai pasar yang cukup potensial karena mempunyai kantor baru yang terletak di Ruko Grand Ahmad Yani 151-P, Jl. Ahmad Yani Frontage Road Surabaya yang sangat strategis karena termasuk kawasan yang sangat ramai sehingga memudahkan KSPPS BMT Amanah Ummah dalam menarik para mitra untuk mau begabung dengan BMT ini. KSPPS BMT Amanah Ummah juga pernah menerima penghargaan dari Gubernur Jawa Timur sebagai koperasi yang berkinerja terbaik pertama pada tahun 2014 (Sumber: http/ http://kjksamanahummah.blogspot.co.idAgustus-2016, diakses pada 13 Agustus 2016). Walaupun letaknya sangat stategis KSPPS BMT Amanah Ummah tetap harus mampu untuk menciptakan produkproduk unggulan yang layak dan dapat dengan mudah diterima mayarakat. Itu semua dikarenakan persaingan usaha di 
sektor perbankan sangat ketat, belum lagi persaingan itu datang dari lembaga non perbankan. Salah satu kendala utama dalam Baitul Maal Wat Tamwil adalah modal yang kurang memadai untuk operasional BMT. Maka dari itu perlunya strategi pengembangan produk funding untuk meningkatkan minat masyarakat menabung di BMT.

Dari berbagai pemaparan diatas bahwa problem utama lembaga keuangan mikro khususnya BMT adalah permasalahan pemodalan sehingga BMT harus memiliki strategi yang tepat dalam operasionalnya salah satunya adalah strategi pengembangan produk pendanaannya. Maka penulis tertarik untuk mengkaji dan meneliti lebih dalam lagi terkait dengan Baitul Maal Wat Tamwil (BMT) dan strategi pengembangan produk pendanaanya. Tujuan penelitian ini adalah untuk mengetahui strategi pengembangan produk funding pada BMT Amanah Ummah Jawa Timur.

\section{LANDASAN PUSTAKA}

Baitul Maal Wat Tamwil (BMT) yang lebih luas adalah lembaga yang melakukan kegiatannya untuk tujuan sosial dan niaga dalam rangka mensejahterakan umat yang dilakukan baik dengan menghimpun dana dari masyarakat dan melakukan penyaluran/ pembiayaan dalam sektor usaha riil (fungsi baitul tamwil) dan penyaluran dana/harta kepada yang berhak (fungsi baitul maal). Dengan demikian BMT pada dasarnya merupakan gabungan antara baitul maal dan baitul tamwil yang masing-masing memiliki karakteristik yang berbeda. . Prinsip operasinya di dasarkan oleh prinsip bagi hasil, jual beli dan titipan. Karena itu, meskipun mirip dengan Bank Syariah, bahkan boleh dikata menjadi cikal bakal dari Bank Syariah.

BMT dalam memperluas ruang geraknya dan memiliki badan hukum yang jelas serta agar bisa beroperasi dengan baik, maka sebagian BMT memilih badan hukum Koperasi sesuai dengan Peraturan Menteri Negara Koperasi dan Usaha Kecil dan Menengah Republik Indonesia Nomor 16/Per/M.KUKM/IX/2015 tentang Pelaksanaan Kegiatan Usaha Simpan Pinjam dan Pembiayaan Syariah oleh Koperasi. Pasal 1 ayat 2 menjelaskan bahwa Koperasi Simpan Pinjam dan Pembiayaan Syariah selanjutnya dalam peraturan ini disebut KSPPS adalah koperasi yang kegiatan usahanya meliputi simpanan, pinjaman dan pembiayaan sesuai prinsip syariah, termasuk mengelola zakat, infaq/sedekah, dan waqaf.

Peraturan Menteri Negara Koperasi dan Usaha Kecil dan Menengah Republik Indonesia Nomor:35.3/Per/M.KUKM/X/2007 pasal 1 menjelaskan bahwa Koperasi adalah badan usaha yang beranggotakan orang seorang atau badan hukum koperasi dengan melandaskan kegiatannya berdasarkan prinsip koperasi sekaligus sebagai gerakan ekonomi rakyat yang berdasar atas asas kekeluargaan. Sedangkan Koperasi Jasa Keuangan Syariah, selanjutnya disebut KJKS, adalah Koperasi yang kegiatan usahanya bergerak di bidang 
pembiayaan investasi, dan simpanan sesuai pola syariah.

\section{Strategi Pengembangan Produk Keuangan Islam}

Produk dalam lembaga keuangan syariah khusunya BMT mempunyai dua jenis produk utama yakni produk penghimpunan dan penyaluran dana yang secara teknis-financial dapat dikembangkan BMT untuk menjalankan usahanya, seperti penghimpunan dana syariah.

Tujuan pengembangan produk menurut Alma (2002:101) adalah untuk memenuhi konsumen yang belum puas, untuk menambah omzet penjualan, untuk memenangkan persaingan, untuk mendayagunakan sumber-sumber produksi, untuk meningkatkan keuntungan dengan pemakaian bahan yang sama, untuk mendayagunakan sisa-sisa bahan, untuk mencegah kebosanan konsumen.

Menurut Mawardi, Skema pengembangan produk keuangan islam haruslah ada unsur kebutuhan pasar, pemenuhan kebutuhan syariah dan memenuhi Maqashid syariah, seperti yang terdapat pada gambar 2.1:

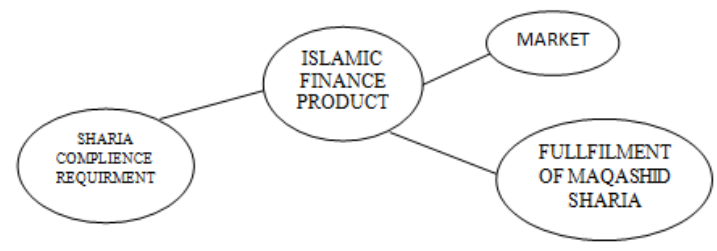

Gambar 1

Skema Pengembangan Produk Keuangan Islam

Menurut Al-Suwailem (2006:104)

"the next step in Islamic financial engineering is to examine strategies and techniques for developing financial products. There are generally three strategies, depending on the starting point of the development process: to start from conventional product, to start from Islamic product, to start from the real needs of customers." Dalam bukunya Suwailem menjelaskan bahwa ada 3 strategi dalam mengembangkan produkproduk keuangan yakni dimulai dari produk konvesional, dimulai dari produk syariah dan dari kebutuhan rill konsumen.

The first strategy is to have a conventional but Islamically questionable) product as a reference, and then use Islamic contract to construct an equivalent product with almost identical properties (Al-Suwilem, 2006:105). Strategi pertama dengan memiliki produk konvesional (namun yang secara syariah dipertanyakan) sebagai referensi, dan kemudian menggunakan cara kerja syariah untuk membangun produk yang hampir sama. Strategi ini disebut strategi imitasi.

The second strategy is to start from acceptable Islamic products, and try different variations and modifications on them, and see how the resulting products could be used. Using the jargon of genetic algorithms (GA), existing product will be subjected to mutations and cross-over, then using a selection criterion based on degree of integration (Al-Suwilem, 2006:107). Strategi kedua ini memulai dari produk syariah yang sudah diterima di masyarakat kemudian membuat 
berbagai variasi baru dan memodifikasi pada produk tersebut, dan melihat bagaimana produk yang dihasilkan dapat digunakan kemudian menggunakan kriteria seleksi berdasarkan tingkat integrasi. Strategi bisa menghasilkan jumlah produk yang efektif dan tidak terbatas, mengingat bahwa titik awal produk sudah diterima dan sesuai syariah.

The third strategy starts from actual needs costumers, then go back and see which products or design could serve these needs. The strategy works in the opposite direction of the previous strategy, and therefore teh two complement each other (Al-Suwilem, 2006:108). Strategi ketiga dimulai dari melihat kebutuhan pelanggan/ masyarakat yang sebenarnya kemudian kembali melihat produk atau mendesain produk sesuai kebutuhan masyarakat/ pelanggan. Strategi ini bekerja dalam arah yang berlawanan dari strategi sebelumnya, dan karena itu keduanya saling melengkapi.

Pada pandangan Islam tugas manusia adalah melakukan usaha semaksimal mungkin untuk mendapatkan rezeki dengan cara yang sebaik-baiknya. Salah satunya dengan jalan berbisnis dan terus menerus berusaha, la tidak akan takut kekurangan rezeki atau kehilangan rezeki hanya karena anggapan rezeki itu di ambil pesaing. Namun tetap berikhtiyar untuk mencapai yang terbaik. Hal ini dijelaskan dalam ayat Al-quran Al-Mulk ayat 15.

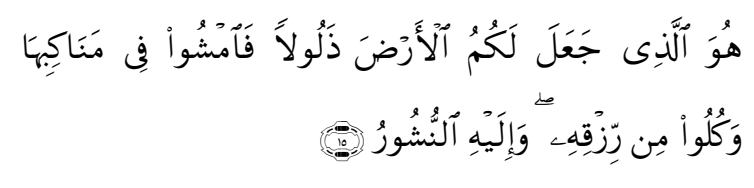

"Huwa Al-Ladhì Ja'ala Lakumu Al-'Arđa Dhalūlāan Fāmshū Fı Manākibihā Wa Kulū MinRizqihiWa 'llayhi An-Nushūru."

"Dialah yang menjadikan bumi itu mudah bagi kamu, maka berjalanlah di segala penjurunya dan makanlah sebahagian dari rezekiNya, dan hanya kepada-Nyalah kamu (kembali setelah) dibangkitkan."

Keyakinan bahwa rezeki sematamata datang dari Allah SWT akan menjadi kekuatan ruhiyah bagi seorang pembisnis muslim untuk terus berikhtiyar dalam memasarkan produk terbaiknya untuk mencapai keunggulan bersaing pada dengan lembaga keuangan syariah lainnya. Keyakinan ini menjadi landasan sikap tawakal yang kokoh dalam berbisnis. Selama berbisnis, la sandarkan segala sesuatunya kepada Allah. Manakala bisnisnya memenangkan persaingan, la bersyukur. Sebaliknya, ketika terpuruk dalam bersaing, la bersabar. Intinya segala keadaan ia hadapi dengan sikap positif tanpa meninggalkan hal-hal prinsip yang telah Allah perintahkan kepadanya.

\section{METODE PENELITIAN}

\section{Pendeketan penelitian}

Penelitian ini menggunakan pendekatan kuaalitatif. Penelitian ini dilaksanakan dengan harapan mampu menjawab pertanyaan: bagaimana strategi pengembangan produk funding pada KSPPS BMT Amanah Ummah Jawa Timut? 
Penelitian ini menggunakan strategi studi kasus. Menurut Yin (2013:1) metode studi kasus adalah strategi yang lebih cocok bila pokok pertanyaan suatu penelitian berkenaan dengan "how" dan "why", bila peneliti hanya sedikit memiliki peluang untuk mengontrol peristiwaperistiwa yang akan diselidiki, dan bila mana fokus penelitian terletak pada fenomena masa kini didalam konteks kehidupan nyata.

\section{Ruang Lingkup Penelitian}

Ruang lingkup dalam penelitian ini fokus pada rumusan masalah yang telah ditentukan sebelumnya yaitu, bagaimana strategi pengembangan produk funding pada KSSPS BMT Amanah Ummah dalam meningkatkan keunggulan bersaing. Ruang lingkup pertama, terbatas pada produk yang diteliti yaitu hanya produk funding atau pendanaannya saja. Kedua, strategi pengembangan produk funding pada KSPPS BMT Amanah Ummah.

\section{Jenis dan Sumber data}

Adapun data yang diperlukan dalam penelitian ini adalah data primer (Utama) dan dan data sekunder (penunjang). Data primer dapat diperoleh melalui wawancara secara langsung terhadap objek terkait. Sedangkan data sekunder dapat diperoleh dengan cara membaca dan mengumpulkan literatur-literatur yang berkaitan dengan topik penelitian.

\section{Unit Analisis}

Dalam unit analisis ini Peneliti menggunakan teknik purposive sampling dalam menentukan informan dari penelitian. Dalam penelitian ini unit analisis adalah pengelola dan pengurus yang mengetahui strategi pengembangan produk pendanaan yang ada pada KSPPS BMT Amanah Ummah Jawa Timur.

\section{Pengumpulan data}

Langkah-langkah memperoleh data adalah sebagai berikut :

a. Menyelesaikan birokrasi dan surat ijin penelitian pada Fakultas Ekonomi Dan Bisnis Universitas Airlangga.

b. Mendatangi objek penelitian dan melakukan wawancara terhadap informan terkait.

\section{Teknik Analisis Data}

Adapun teknik analisa data yang digunakan adalah teknik penjodohan pola (pattern matching), yaitu logika penjodohan adalah membandingkan pola yang didasarkan atas empiris dengan pola yang diprediksikan (Yin, 2013: 140). Dalam hal ini peneliti melakukan perbandingan antara teori empiris yang terdapat pada bab sebelumnya dan proposisi yang telah dibuat dengan data yang diperoleh dari hasil wawancara terhadap informan yaitu pengelola dan pengurus KSPPS BMT Amanah Ummah Jawa Timur. Semakin besar persamaan antara kedua pola tersebut maka semakin menguatkan pula pada validitas internal studi kasus yang bersangkutan. 
IV. Hasil dan Pembahasan

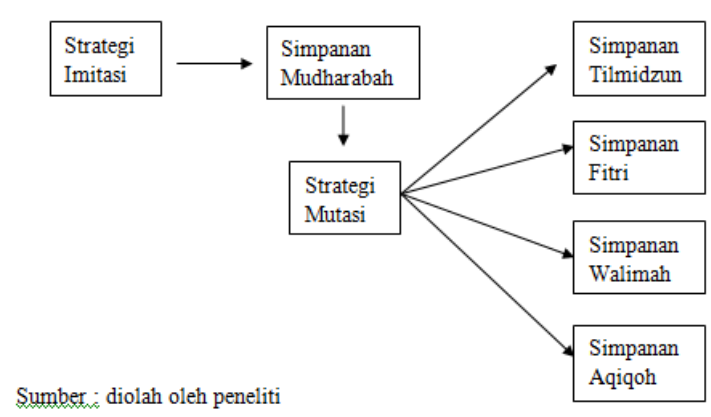

Gambar 2

Strategi Pengembangan Produk Simpanan Harian

KSPPS BMT Amanah Ummah melakukan pengembangan produk simpanan harian yang pada awalnya produk-produk simpanan di BMT Amanah Ummah dikembangkan dengan Strategi Imitasi yaitu mengimitasi dari produk konvensional yang juga telah diterapkan pada lembaga-lembaga keuangan syariah yang lain, salah satunya pada BMT di Jawa Tengah yang dikunjungi oleh pihak BMT Amanah Ummah untuk melakukan studi banding. Produk simpanan mudharabah sebenarnya diadopsi atau diimitasi dari produk yang terdapat di lembaga keuangan konvesional seperti Bank Konvesional maupun Koperasi Konvesional yaitu simpanan atau tabungan, hanya saja tabungan itu tidak sesuai syariah karena menggunakan bunga, namun karena masyarakat sudah sangat familiar dengan istilah tabungan itu maka, produk ini tetap digunakan dengan nama simpanan mudharabah yang akadnya tidak lagi menggunakan bunga tetapi dengan bagi hasil.
Pengembangan produk simpanan harian selanjutnya lebih banyak menggunakan pendekatan Strategi Mutasi yaitu memodifikasi dari produk simpanan syariah yang sudah ada disesuaikan dengan kebutuhan masyarakat. Produk-produk yang dikembangkan dengan strategi mutasi ini antara lain Simpanan Tilmidzun, Simpanan Fitri, Simpanan Walimah, Dan Simpanan Aqiqoh.

Simpanan Tilmidzun adalah produk simpanan harian pada BMT Amanah Ummah yang menggunakan akad Mudharabah Mutlaqah yang secara prinsip merupakan pengembangan dari produk simpanan yang sudah ada yakni Simpanan Mudharabah, sehingga disebut menggunakan strategi mutasi karena secara dasar pengembangan produknya adalah modifikasi yang disesuaikan dengan tujuan produk yakni sebagai simpanan khusus untuk anak usia sekolah yang diutamakan untuk kebutuhan sekolah serta mendidik anak menjadi gemar menabung. Penyetoran dan penarikan Produk Simpanan Harian Tilmidzun dapat dilakukan setiap saat namun lebih diutamakan untuk kebutuhan sekolah. Produk Simpanan Harian Tilmidzun juga memberikan bagi hasil yang kompetitif sesuai dengan syariah.

Simpanan Fitri adalah produk simpanan harian pada BMT Amanah Ummah yang menggunakan akad Mudharabah Mutlaqah yang secara prinsip merupakan pengembangan dari produk simpanan yang sudah ada yakni 
Simpanan Mudharabah, sehingga disebut menggunakan strategi mutasi karena secara dasar pengembangan produknya adalah modifikasi yang disesuaikan dengan tujuan produk yakni sebagai simpanan yang membantu kebutuhan anggota untuk menyambut Hari Raya Idul Fitri. Penyetoran dan penarikan Produk Simpanan Harian Tilmidzun dapat dilakukan setiap saat namun lebih diutamakan untuk kebutuhan Hari Raya Idul Fitri Produk Simpanan Harian Fitri juga memberikan bagi hasil yang kompetitif sesuai dengan syariah serta memberikan bingkisan parcel kepada anggota yang menabung melebihi target yang ditentukan oleh pihak KSPPS BMT Amanah Ummah.

Simpanan Walimah adalah produk simpanan harian pada BMT Amanah Ummah yang menggunakan akad Mudharabah Mutlaqah yang secara prinsip merupakan pengembangan dari produk simpanan yang sudah ada yakni Simpanan Mudharabah, sehingga disebut menggunakan strategi mutasi karena secara dasar pengembangan produknya adalah modifikasi yang disesuaikan dengan tujuan produk yakni sebagai simpanan yang membantu menyiapkan kebutuhan walimah maupun pernikahan. Penyetoran dana dapat dilakukan sewaktu-waktu sedangkan penarikan Produk Simpanan Harian Walimah hanya dapat dilakukan pada saat menjelang pelaksanaan walimah atau pernikahan. Produk Simpanan Harian Walimah juga memberikan bagi hasil yang kompetitif sesuai dengan syariah.

Simpanan Aqiqoh adalah produk simpanan harian pada BMT Amanah Ummah yang menggunakan akad Mudharabah Mutlaqah yang secara prinsip merupakan pengembangan dari produk simpanan yang sudah ada yakni Simpanan Mudharabah, sehingga disebut menggunakan strategi mutasi karena secara dasar pengembangan produknya adalah modifikasi yang disesuaikan dengan tujuan produk yakni sebagai simpanan yang direncanakan untuk mempersiapkan kebutuhan aqiqoh. Penyetoran dana dapat dilakukan sewaktu-waktu sedangkan penarikan Produk Simpanan Harian Aqiqoh dilakukan pada saat menjelang pelaksanaan aqiqoh. Produk Simpanan Harian Aqiqoh juga memberikan bagi hasil yang kompetitif sesuai dengan syariah.

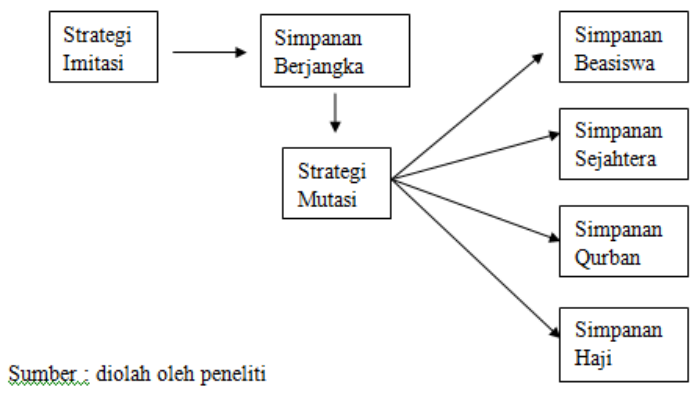

\section{Gambar 3 \\ Strategi Pengembangan Produk Simpanan Berjangka \\ Simpanan Berjangka Mudharabah} ini juga diimitasi dari produk konvensional yaitu Deposito Berjangka, karena deposito juga menggunakan bunga dan itu tidak sesuai dengan syariah maka ini diimitasi, produk Simpanan Berjangka Mudharabah tetap sama dengan produk Deposito 
Berjangka di konvesional tetapi sudah disesuaikan menggunakan akad syariah. Sesuai dengan Suwailem strategi yang digunakan adalah Strategi Imitasi yakni mengadopsi atau meniru produk yang ada di lembaga keuangan konvesional kemudian disesuaikan dengan prinsipprinsip syariah.

Pengembangan produk simpanan berjangka berikutnya lebih banyak menggunakan pendekatan Strategi Mutasi yaitu memodifikasi dari produk simpanan syariah yang sudah ada yang disesuaikan dengan kebutuhan masyarakat. Produk-produk yang dikembangkan dengan strategi mutasi ini antara lain Simpanan Beasiswa, Simpanan Sejahtera, Simpanan Qurban, dan Simpanan Haji.

Simpanan Beasiswa adalah produk simpanan berjangka pada BMT Amanah Ummah yang menggunakan akad Mudharabah Mutlaqah yang secara prinsip merupakan pengembangan dari produk simpanan yang sudah ada yakni Simpanan Berjangka Mudharabah, sehingga disebut menggunakan strategi mutasi karena secara dasar pengembangan produknya adalah modifikasi yang disesuaikan dengan tujuan produk yakni sebagai simpanan khusus untuk mempersiapkan dana pendidikan anak saat mmasuki jenjang pendidikan dasar hingga perguruan tinggi. Penyetoran dan penarikan Produk Simpanan Berjangka Beasiswa dilakukan sesuai kesepakatan (1 bulan, 3 bulan, 6 bulan, 9 bulan, 12 bulan) atau sesuai ketentuan. Simpanan Harian Tilmidzun dan Simpanan Berjangka Beasiswa memilki kesamaan tujuan yaitu untuk mempersiapkan pendidikan, hanya saja target pasar Simpanan Harian Tilmidzun adalah anak-anak sekolah dengan setoran tabungannya fleksibel sedangkan Simpanan Berjangka Beasiswa targetnya lebih ke orang tua yang mempersiapkan pendidikan untuk anaknya dengan setoran dan penarikannya sesuai kesepakatan.

Simpanan Sejahtera adalah produk simpanan berjangka pada BMT Amanah Ummah yang menggunakan akad Mudharabah Mutlaqah yang secara prinsip merupakan pengembangan dari produk simpanan yang sudah ada yakni Simpanan Berjangka Mudharabah, sehingga disebut menggunakan strategi mutasi karena secara dasar pengembangan produknya adalah modifikasi yang disesuaikan dengan tujuan produk yakni sebagai simpanan yang membantu merencanakan kevangan di masa depan. Sistem setoran rutin setiap bulan dan penarikan Produk Simpanan Berjangka Beasiswa dilakukan sesuai kesepakatan (1 bulan, 3 bulan, 6 bulan, 9 bulan, 12 bulan) atau sesuai ketentuan. Setoran awal Rp 100.000,-. Produk Simpanan Berjangka Sejahtera juga memberikan porsi bagi hasil hingga $76 \%$ dari laba operasional untuk anggota. Simpanan Sejahtera adalah simpanan berjangka yang paling terakhir diciptakan.

Simpanan Qurban adalah produk simpanan berjangka pada BMT Amanah 
Ummah yang menggunakan akad Mudharabah Mutlaqah yang secara prinsip merupakan pengembangan dari produk simpanan yang sudah ada yakni Simpanan Berjangka Mudharabah, sehingga disebut menggunakan strategi mutasi karena secara dasar pengembangan produknya adalah modifikasi yang disesuaikan dengan tujuan produk yakni sebagai simpanan yang diperuntukkan untuk anggota yang ingin melakukan pembelian hewan qurban untuk Hari Raya Idul Adha sesuai ketentuan syar'i dan kesehatan. Sistem setoran rutin selama 11 (sebelas) bulan. Pada Simpanan Qurban ini pihak BMT bekerja sama dengan pengelola perternakan yang juga melakukan pembiayaan di BMT Amanah Ummah.

Simpanan Haji adalah produk simpanan berjangka pada BMT Amanah Ummah yang menggunakan akad Mudharabah Mutlaqah yang secara prinsip merupakan pengembangan dari produk simpanan yang sudah ada yakni Simpanan Berjangka Mudharabah, sehingga disebut menggunakan strategi mutasi karena secara dasar pengembangan produknya adalah modifikasi yang disesuaikan dengan tujuan produk yakni sebagai simpanan yang diperuntukkan untuk anggota yang ingin pergi Haji dengan fasilitas dana talangan agar mendapatkan porsi keberangkatan haji. Sistem setoran rutin setiap bulan sampai terpenuhinya dana yang dibutuhkan. Pihak BMT bekerja sama dengan travel-travel Haji dalam pelaksanaanya.

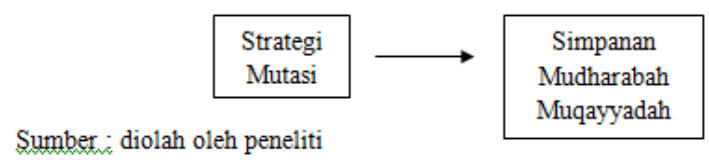

Gambar 4

Strategi Pengembangan Produk Simpanan Kondisional

Simpanan

Mudharabah Muqayyadah adalah produk simpanan pada BMT Amanah Ummah yang terdapat batasan-batasan tertentu dalam pengelolaan dananya. Simpanan Mudharabah Muqayyadah bersifat kondisional sesuai dengan proyek yang akan dibiayai. akad Mudharabah Muqayyadah secara prinsip merupakan pengembangan dari produk simpanan yang sudah ada yakni Simpanan Berjangka Mudharabah dengan akad yang disesuaikan kebutuhan. Menggunakan akad Mudharabah Muqayyadah karena dana yang dititipkan oleh anggota kepada BMT tidak bisa diberikan secara fleksibel pada pembiayaan yang ada pada BMT, dana tersebut harus diberikan pada satu proyek yang sudah disepakati bersama. Sehingga Simpanan Mudharabah Muqayyadah disebut menggunakan strategi mutasi karena secara dasar pengembangan produknya adalah modifikasi yang disesuaikan dengan tujuan produk yakni sebagai simpanan atau investasi untuk suatu proyek tertentu dengan nisbah bagi hasil yang disepakati bersama. Sistem simpanan ini fleksibel tergantung kebutuhan, karena BMT hanya sebagai 
lembaga intermediasi, bisa saja pihak yang memilki proyek menawarkan kepada pihak BMT untuk membiayai proyeknya atau sebaliknya pihak Shahibul Maal menawarkan dananya untuk pendanaan Simpanan Mudharabah Muqayyadah.

Secara ringkas strategi yang digunakan oleh KSPPS BMT Amanah Ummah dalam pengembangan produknya dapat diklasifikasikan seperti tabel berikut ini :

Tabel 1

Strategi Yang Digunakan Pada Produk Funding

KSPPS BMT Amanah Ummah Jawa Timur

\begin{tabular}{|l|l|l|l|}
\hline NO & $\begin{array}{l}\text { NAMA PRODUK } \\
\text { FUNDING }\end{array}$ & \multicolumn{1}{|c|}{ AKAD } & STRATEGI \\
\hline 1 & $\begin{array}{l}\text { Simpanan } \\
\text { Mudharabah }\end{array}$ & Mudharabah Mutlaqah & Strategi Imitasi \\
\hline 2 & $\begin{array}{l}\text { Simpanan } \\
\text { Tilmidzun }\end{array}$ & Mudharabah Mutlaqah & Strategi Mutasi \\
\hline 3 & Simpanan Fitri & Mudharabah Mutlaqah & Strategi Mutasi \\
\hline 4 & Simpanan Qurban & Mudharabah Mutlaqah & Strategi Mutasi \\
\hline 5 & Simpanan Walimah & Mudharabah Mutlaqah & Strategi Mutasi \\
\hline 6 & Simpanan Aqiqoh & Mudharabah Mutlaqah & Strategi Mutasi \\
\hline 7 & $\begin{array}{l}\text { Simpanan } \\
\text { Berjangka }\end{array}$ & Mudharabah Mutlaqah & Strategi Imitasi \\
\hline 8 & Simpanan Beasiswa & Mudharabah Mutlaqah & Strategi Mutasi \\
\hline 9 & Simpanan Haji & Mudharabah Mutlaqah & Strategi Mutasi \\
\hline 10 & Simpanan Sejahtera & Mudharabah Mutlaqah & Strategi Mutasi \\
\hline 11 & $\begin{array}{l}\text { Simpanan } \\
\text { Mudharabah } \\
\text { Muqayyadah }\end{array}$ & $\begin{array}{l}\text { Mudharabah } \\
\text { Muqayyadah }\end{array}$ & Strategi Mutasi \\
\hline.. & $\ldots$ & & \\
\hline
\end{tabular}

\section{Simpulan}

Berdasarkan hasil dari pembahasan sebelumnya dapat disimpulkan bahwa pada awalnya strategi pengembangan produk KSPPS BMT Amanah Ummah Jawa Timur menggunakan strategi Imitasi karena menyesuaikan dengan apa yang sudah dipahami dan familiar di masyarakat yakni produk-produk simpanan konvensional. Produk yang menggunakan strategi imitasi ini adalah produk simpanan mudharabah dan produk simpanan berjangka mudharabah. Selain itu, sebagian besar strategi pengembangan produk berikutnya menggunakan pendekatan strategi mutasi yaitu dengan memodifikasi produk-produk simpanan syariah yang sudah dimiliki maupun di mutasi dari produk-produk simpanan yang ada di lembaga keuangan syariah yang lain sesuai dengan kebutuhan anggota yaitu produk Simpanan Tilmidzun, Simpanan Fitri, Simpanan Walimah, Simpanan Aqiqoh, Simpanan Beasiswa, Simpanan Sejahtera, Simpanan Qurban, Simpanan Haji dan Simpanan Mudharabah Muqayyadah.

\section{DAFTAR PUSTAKA}

Alma, Buchari. 2002. Manajemen dan Pemasaran Jasa, edisi ke 5. Bandung: Alfabeta

Al-Suwailem, Sami. 2006. Hedging In Islamic Finance. Jeddah: King Fahad National Library Cataloging-In-Publication Data

Departemen Agama Republik Indonesia. 2006. Al-quran Dan Terjemahannya. Jakarta: CV. Pustaka Agung Harapan Huda, Nurul dan Mohammad Heykal. 2010. Lembaga Keuangan Islam: Tinjauan Teoritis dan Praktis. Jakarta: Kencana

Republik Indonesia. Menteri Negara Koperasi Dan Usaha Kecil Dan Menengah Republik Indonesia. 2007. Peraturan Nomor: 35.3/Per/M.KUKM/X/2007.

Tentang Pedoman Penilaian Kesehatan Koperasi Jasa Keuangan Syariah Dan Unit Jasa Kevangan Syariah Koperasi. Undang-undang Republik 
Indonesia No. 10 Tahun 1998

tentang Perbankan.

Menteri Negara Koperasi Dan

Usaha Kecil Dan Menengah

Republik Indonesia. 2015.

Peraturan Nomor:

16/Per/M.KUKM/IX/2015. Tentang

Pelaksanaan Kegiatan Usaha

Simpan Pinjam Dan Pembiayaan

Syariah Oleh Koperasi.

Shufyan, Bahri Interview. 2016. "Interview of BMT Problem". Jl Ahmad Yani $121-\mathrm{P}$

Sudarsono, Heri. 2007. Bank dan Lembaga Kevangan Syariah: Deskripsi dan Ilustrasi. Yogyakarta: Ekonisia

Yin, Robert K. 2009. Studi Kasus: Desain \& Metode. Jakarta: Raja Grafindo Persada

Yin, Robert K. 2013. Studi Kasus Desain \& Metode. Jakarta: Rajawali Pers Mawardi, Imron. 2015. Pengembangan Produk Keuangan Islam. Dalam Mata Kuliah Pengembangan Produk Keuangan di Universitas Airlangga.

http://kjksamanahummah.blogspot.co.idAgustus-2016, diakses pada 13 Agustus 2016 